\title{
The Role of Agency and Institutional Theory in the Planning and Realization for Capital Expenditures
}

\author{
Syaiful Hifni ${ }^{\varpi}$ \\ Faculty of Economics, Universitas Lambung Mangkurat, Indonesia \\ Jl. Brigjen Haji Hasan Basri No.29 Banjarmasin, Kalimantan Selatan, Indonesia
}

DOI: http://dx.doi.org/10.15294/jda.v9i1.12001

Received: 12 October 2016. Revised: 22 December 2016. Accepted: 2 February 2017. Published: 31 March 2017

\begin{abstract}
The capital expenditures are part of direct expenditure in the regional budget. The other elements of capital expenditures are: personnel expenditure, and spending on goods and services. Planning and realization for capital expenditure in the regional budget for each Government Regional Work Units is a part of policy regional financial management in fiscal decentralization policy which need be increased to achieve value significantly over time. Increasing in planning and realization of capital expenditures is directly related to the amount of capital expenditure element that strengthens physical infrastructure which would strengthen economic growth for social welfare, regional competitiveness for facilitation and liberalization a single market and production base in AEC era. This study examines the role of agency theory and institutional theory in relation with planning and realization of capital expenditures of 82 (Eighty Two) Government Work Units of 3 (Three) regional government, namely Banjarmasin City, Banjar District, and Tanah Laut District in South Kalimantan Province. This study contributes to the accounting literature to assess role of conceptual framework with agency theory and institutional theory. The result of study showed: there are differences in the implementation of capital expenditure to meet AEC pillars and social welfare purposes by increasing capital expenditure through the role of the agency theory, and institutional theory. Relationship of agency theory and institutional theory with social welfare and AEC with the amount of C Contingency coefficient 0,313 and Cramer Coefficient of Association 0.191 indicates there are "Moderate correlation: substantial relationship" and "Small correlation; Lower relationship association.
\end{abstract}

Keywords: Capital Expenditure; Theory of Agency; Institutional Theory; Social Welfare; ASEAN Economi Community (AEC)

How to cite (APA 6th Style)

Hifni, S. (2017). The Role of Agency and Institutional Theory in the Planning and Realization for Capital Expenditures. Jurnal Dinamika Akuntansi, 9(1), 33-48.

\section{INTRODUCTION}

The decision making process of planning and realization of direct expenditure carried out referring to regulation in the financial management of the State / Region. To fulfill the duty in development, every regional government should prepare and create the budget framework and the regulatory framework of capital expenditure, as part of direct expenditures and as part regional expenditures which has the goal to achieve social welfare in realtion with the regional autonomous

Syaiful Hifni $(\bowtie)$

E-mail: ahmad@ulm.ac.id 
in Indonesia. In Article 2 of Law No. 17 of 2003 on State Finance, stated one of the country's financial scope is regional expenditure/regional spending. In this Act states, that government expenditure and regional expenditure was detailed down to organizational units, functions, programs, activities and types of expenditure. Spending classified into 2 (two) categories, namely: direct expenditure, and indirect expenditure. Sidik (2007) argue that financial responsibility is a core component of decentralization. Fiscal decentralization AECns setting limits for decision making at the sub-national level by strengthening the power and responsibilities of lower tiers of public administration in providing and financing public goods and services. Government expenditure comprises three broad kinds of expenditure: (i) Transfer or benefiit, (ii) provisison of public services, and (iii) administration. The first category consists mainly of welfare and super payments, where the crown distributes money to people without expectation of a service of any kind to be provided. Public services include both direct government provision of services such as health and education as well as funding others to provide these services. Public administration which includes spending to provide policy advice, construct and enforce regulation, standard setting, and other administration related to the core functions of governmennt (NZIER, 2013).

According to Law on State Finance, decision plans and budgeting as well as decision of capital expenditures realization are part of a system of financial management referring to local budgets instrument. This process includes a number of phases, where each phase requires the activity of decision-making in meeting planning management output namely Budget Work Plan (BWP) and Document of realization of direct expenditure in the Budget Execution Document (BED). Planning and realization of capital expenditure which referring to program/activities in local government is part of the participation process of budgeting, the establishment of the project or activity as an activity that involves many aspects through the attitude of managerial Budget Team for the performance of decision, as the way in which projects are planned and carried out follows a sequence beginning with an agreed strategy. Project management is the process of developing substantive, systematic data about each parameter in order to maximize the effectiveness of the decision. (Govindarajan, 1986, EC, 2002; HBS, 2002). Starting from the aspect of regulation as the primary basis for the policy to determine Budget Work Plan of GWUs and Budget Execution List of GWUs for capital expenditure/spending activity in the regional budget instrument.

Perspective of planning decisions and realization of capital expenditures is as contingency (Otley, 1980), because the result of this process be determined with many different aspects in every decision-making environment. This perspective describing that no information system that is universally applicable to all circumstances and at all locations of its application. This theory explains there are other situational factors that interact in influencing certain situations. Brownell (1982), and Govindarajan (1986), describes classification aspects of contingency and individual and organizational attributes as a variable that is contingency. The variables are expressed as contingency factors that influence the planning and control systems within the organization.

In policy making was needed the conceptual framework approach for relevant strengthening of regulatory formal as reference in the decision of the planning and realization of capital expenditure. As the implementation of the decisions related to public policy, the explanations can be taken through the agency theory (Jensen \& Meckling, 1976), and as well as institutional theory (DiMaggio and Powell, 1983). Perspective of agency theory put forward in accordance with the description that: "...conclusion drawn from formal economic models (i.e. agency theory) that ignored the behavioral factor should be interpreted cautiously" (Kren, 1997). AEC's while, DiMaggio and Powell (1983), put forward the concept of isomorphic mechanisme which described as competitive isomorphism and institutional isomorphism. The concept of competitive isomorphism with regard to the description of the organization's efficiency and economic survival of the organization, while the institutional isomorphism with regard to the strength of their social environment that gives rise to a certain pressure for organizations to be able to develop certain practices that can be accepted in the organizational environment. 
The combination of the regulation framework and theoretical framework is required for fulfill planning and realization of capital expenditures. This process will involves many parties in planning and determining of capital expenditure, so that will cause conflicts of interest. Appropriate Agency Theory (Jensen \& Meckling, 1976), explains the key points related to "agency relationship" which describes the contractual relationship between the agent and the principal or the stakeholders, the "divergent interests" and goals. In balancing the relationship with the "principal", whether the agent has acted appropriate and in-appropriate, because the agent has managerial opportunism. This concept describes the tendency of the attitude of behavior in specific actions to meet their own interests. Managerial opportunism inhibit prosperity principal on the main objective to be achieved organization. To explain the phenomenon of self-interest in the public budgeting, agency theory can be used as a theoretical basis (Smith \& Bertozzi, 1998).

Based on relation in "A Principal-Agent Theory Approach" to Public Expenditure Management in Developing Countries, be stated a well-functioning public expenditure management (PEM) system is considered a critical pillar of government efficiency (Luc and Elisabeth, 2006). Meanwhile, Shantayana et al., (1996), has showed: "Using data from 43 developing contries over 20 years we show that an increase in the share of current expenditure has positive and statistically significant growth effects. By contrast, the relationship between the capital component of public expenditure and per capita growth is negative. Thus, seemingly productive expenditure when used in excess could become unpredictive. These results imply that developing contry government have been misallocating public expenditures in favor of capital expenditures at the expense of current expenditures (Shantayana et al., 1996).

Institutional theory has explanation tool in the form of the concept of isomorphism. This concept is a tool or a trigger that explains how and why the organization will ultimately have a tendency to move from diversity (diversity) to the level of equalization or similarity (similarity). Di Maggio and Powell (1983) suggested a mechanism isomorpik among others in the form of Competitive isomorphism, as a reference for the practice of the organization's efficiency and survival of economically from the organization, and Institutional isomorphism as the strength of the social environment which gave specific pressure for institutions / organizations to be able to develop organizational practice which accepted by the organization (DiMaggio \& W. Powell, 1983). This theory as a complement of the economic theory that has the common AECning (in general), and the special significance (particular) is Expressed as a resource dependency theory (Carpenter \& Feroz, 2001). Appropriate description of this theory, the integration of institutional theory and the theory of resources dependency is to develop a theoretical framework that helps explain an election process in planning decisions and decision taking in realization. This referring to the accountability of economic resource allocation for organization.

Appropriate mechanism refers to the regulation (Government Regulation No. 25 of 2004) describes the stages in the planning and realization of capital expenditure as part of the forming projected value of direct expenditure in Budget Work Plan of Governmental Work Units (GWUs) and determination of its realization in Budget Execution Document (BED) of GWUs. This stage shall refer to the stages of the activity: (i) the stage of determination Budget General Policy (BGP), which based on (Regional development plan in medium term / Government Work plan, aspirations of stakeholders, the performance of the previous period, the basic assumptions in economic, and policy development related to the development priorities). BGP containing program / activities with indicative ceiling value. (ii) the determination "Priorities and Ceiling Budget While" which was discussed between the executive and parliament. This stage as fulfilment a planning process which produces documents Work Plan Budget of GWUs. (iii) determination of the realization budget as evaluation process stage to determine the Budget Execution/Realization Document of GWUs. Fulfillment for the stages above involve various aspects which into consideration for decision-making based on compliance with regulatory aspects.

Relevance of capital expenditure planning and its realization has implications for the achievement of good governance for local governments. This thing related with regard to efforts 
to suppress errors in the implementation of financial management procedures. This is related to the phenomenon (Garamfalvi (1997), which states that corruption can occur at all levels of budgeting, from planning to the payment of public funds. The phenomenon of corruption is politically (political corruption) can occur in the phase of planning and budgeting, as at this stage a political decision is dominant, there is a way to redirect the allocation of public resources. Then, the context of corruption occurring in the implementation of the budget is administrative corruption (administrative corruption), in this case due to the administrative decisions which are predominant. the phenomenon develops where there is a potential political corruption will lead to administrative corruption. Because of regulatory compliance (ex ante, ex post) for financial management, adherence to internal controls, compliance with accounting standards, and transparency in the management of government as the condition for the fulfillment of good governance.

Therefore, future research ought to focus more on the idea-based endogenous growth models to check the robustness of Policy Recommendations. Moreover, the inclusion of hitherto unexplored types of government expenditure, e. g., on the rule of law ", would be desirable (Andreas \& Johanna, 2008). Various studies related to the planning and realization of capital expenditure on the organization has been done. Rating in percentage of the existing of spending on investment to serve the public to the expected of spending on investment to serve the public as a public service quality level of macro-level (Widojono, \& Muzakar, 2013). Planning and realization of capital expenditure in terms of physical infrastructure spending which effectively became the basis for the development goals of social welfare and regional competitiveness in an era of AEC. It is as one component in economic growth in the global environment, namely the accumulation of capital which includes capital expenditure and investment in physical (Todaro, 2006). Econometric analysis of the results of research showed that in the short term, construction spending and employee spending are not significantly influence economic growth, but in the long term development spending significant effect on economic growth statistics, while the labor force has no effect on economic growth (Handoko, 2013). Other studies previously, showed significantly, that there was a relationship between regional economic growth, spending and development expenditure (Adi, 2006, Nworji, 2012). Capital expenditure perspective gives a role to the achievement of development objectives for social welfare and even meet the requirements related to competitiveness in the era of the AEC. In accordance Adi Hari (2006) showed a CR value to the relationship between Spending for Development and Economic Growth amounted to 8.417. It can be concluded that the regional development spending has a positive and significant impact on economic growth.

In this case the role of regulation would guide for decision of plans and realization program/activity referring to capital expenditure projection. Capital expenditures be determined in planning and realization referring to Budget General Policy and "Priorities and Ceiling Budget While " which needs to strengthened with the perspective of agency theory and institutional theory. It will bring and enhance management to achieve relevan decision in order to meet social welfare and also to achieve regional competitiveness in the ASEAN region. the perspective of management in the planning and realization of capital expenditures was needed to achieve objectives the social welfare and in relation to the challenges and implementation of ASEAN Economic Community (AEC) 2015. Indeed, the whole point of a universal welfare policy is not to discriminate between citizens, not to separate "the needy" and "the poor" from other citizens and to treat them differently. Social policy should seek instead a moral obligation to furnish all citizens with, in Amarty Sen's words, basic capabilities (Sen 1982). This stands in contrast to the situation under a selective and a conservative (mixed) system, as the public discourse about social policy in a universal system cannot be conducted in the terms indicated by the question: "what shall we do about these deviant groups/individuals?" (Bo \& Dietlind, 2001).

Other Research result showed that: "The researcher found that there is a statistically significant impact of the current expenses paid on health, economic affairs, and housing and 
community facilities and of the capital expenditures on health and economic affairs on economic growth in Jordan, and there is no statistically significant impact of the current expenses on education and of the capital expenditures on education, housing and community facilities on economic growth in Jordan." (Ali, 2014). "In Paper, be stated the hypothesis that local (municipal) expenditures, in part, can be explained by regional (county) expenditures, with formulate and estimate a demand model for municipal services that is defined conditional on the county expenditures. The results imply a positive dependency between the provision of county and municipal services. Moreover, the results suggest that the hypothesis of weak separability between the provision of county and municipal services can be rejected. In addition, we cannot reject the hypothesis that the regional expenditures are weakly exogenous in the local expenditure equation" (Johan, 2001).

To fulfill duty in development, regional government takes reference namely regulation framework to establish budget framework. Determination for planning and realization of capital expenditure need as decision making process will related to content of decision and environment where decision will taken. This policy referring to decisions which will involves many parties. Jones stated policy definition (1984): "as a standing decision characterized by behavioral consistency on the part of both Reviews those who make it and Reviews those who abide by it". Every establishment of policies will be related to the context of the "who" earned "what" and "how" to get it. There are various aspects determines for the policy implementation.

For global issue, perspective aspect in line with policy implementation has been investigated as antecedent variables that influences performance for implementation. One of this variable is the role of regulation with dimension, namely: (i) goal clarity, (ii) completeness of regulation forms, (iii) acceptance of regulation, and (iv) easiness to apply. (Syaiful, 2013; Mahfud, 2015). The result showed the fact for the weakest of the role of regulation toward the implementation. The weakness associated with the role of regulation which consists of: goal clarity, completeness of regulation forms, acceptance of regulation, and easiness to apply of regulation to support the implementation of the accounting system and performance of information system. This weakness can be appeared as failure to follow form and content of regulation in meet the preventive method (ex ante) from ineffectiveness of accounting system and performance of information system, and failure to avoid punitive (ex post) in administrative punishment form from supervision externally. This empirical facts show the existence of barriers to the effectiveness of achieving accrual base financial reporting in local government.

Based on the description in background, Penelitian ini mencoba untuk memahami secara komprehensif bagaimana perencanaan dan realisasi dari belanja modal pada instansi pemerintahan di Indonesia karena penelitian yang ada sebelumnya tentang Indonesia menurut peneliti baru dipandang secara parsial. This research tries to comprehend comprehensively how the planning and realization of capital expenditure in government institutions in Indonesia because of previous research according to new researchers viewed partially. The research problem was, how do difference and relationship of planning and realization of capital expenditure with the role of the agency theory aspect, the institutional theory aspects and objectives of social welfare for Regional Competitiveness in AEC. Hipothesis test be acted to explain and to predict the phenomenon in decision making process for planning and realization capital expenditure regional governments. Research purposes based on the background and the formulation of the issues raised, is to know how differences and relationship of planning and realization of capital expenditure with the role of the agency theory aspect, the institutional theory aspects and objectives of social welfare for Regional Competitiveness in AEC.

\section{METHODS}

This research is a quantitative research with non-parametric statistical tests.Subjects of research are Government Work units (GWUs) in Banjarmasin City, Banjar District, and Tanah 
Laut District Government. Characteristics of the subjects be selected for each GWU which have Budget Work Plan and Budget execution Document for regional budget yearly. The object of study is the agency theory, and institutional theory, aspects of Social Welfare, and the implementation of AEC. Data were analyzed by analysis of informational and statitistik analysis using nonparametric Chi-square and C Contingency. Phase of data analysis is done by collecting a score for each variable with each indicator. Indicators that fulfilled rated 1 and for indicators that are not met be valued 0 . The maximum number of each indicator of each variable is 5 and the lowest value is 0 . Use of Contingency table, where this table contains the distribution of observed frequencies (Fo) generated from tabulation of scores from each indicator of one variable. Based on data from Fo can be calculated distribution that expected as frequency (Fe)generated by using the formula: $\Sigma \mathrm{ij}=$ ni $x \mathrm{nj} / \mathrm{N}$, where:

$\Sigma \mathrm{ij}=$ frequency distribution of expected in the row and column $\mathrm{i}$ to $\mathrm{j}$

$\mathrm{ni}=$ number of frequencies on the line to $\mathrm{i}$

$\mathrm{nj}=$ number of frequencies in the column to $j$

$\mathrm{N}=$ the total number of frequencies

$\mathrm{i}=1,2,3, \ldots$

$\mathrm{j}-1,2,3, \ldots$

Xo2 calculations generated from the data with the formula :

$\mathrm{rk}$

$\mathrm{Xo} 2=\sum \sum\left(\mathrm{Oij}-\sum \mathrm{ij}\right) 2 / \sum \mathrm{ij}$, where:

$\mathrm{I}=1 \mathrm{j}=1$

$\mathrm{r}=$ Coulumn

$\mathrm{k}=$ row

Oij $=$ observed frequency distribution row $i$ and column $j$

$\Sigma \mathrm{ij}=$ expected frequency distribution row $\mathrm{i}$ and column $\mathrm{j}$

$\mathrm{Xo} 2$ value compared to the value $\mathrm{X} 2$ table, namely to test Ho1 on different test, where if $\mathrm{Xo} 2>\mathrm{X} 2$ table then $\mathrm{H} 01$ can be rejected, and, if Xo2 $<\mathrm{X} 2$ table then $\mathrm{H} 01$ can not be rejected. X2 table is determined according to the table Chi-Square, namely the (row - 1) $\mathrm{x}$ (column 1).The coefficient of Contingency (Contingency C) obtained by the formula: $\mathrm{C}=\sqrt{ } \mathrm{Xo2} / \mathrm{N}+\mathrm{Xo2}$ where: $\mathrm{C}=$ coefficient value is limited ie associations between $0<1$, where: $0=$ no correlation and $1=\mathrm{a}$ perfect relationship

Xo2 $=$ Chi squared observations

$\mathrm{N}=$ number of responses in observation

Contingency coefficient value is also calculated based on the formula Cramer Coeefficient of Association by the formula: $\mathrm{C}=\sqrt{ } \mathrm{Xo} 2 / \mathrm{N}(\mathrm{L}-1)$ for $\mathrm{L}=\min (\mathrm{r} \times \mathrm{c})$. Interpretation of the value of $\mathrm{C}$ based Guilford's Empirical Rule.

Table 1. Guilford's Empirical Rule

\begin{tabular}{ll}
\hline Nilai & Interpretasi \\
\hline $0,0-<0,2$ & Slight correlation : almost negligible relationship \\
$>0,2-<0,4$ & Small correlation; low relationship \\
$>0,4-<0,7$ & Moderate correlation : substantial relationship \\
$>0,7-<0,9$ & High correlation: dependable relationship \\
$>0,9-1$ & Very high correlation: very dependable relationship
\end{tabular}

Source: psycnet.apa.org/index.cfm?fa=buy.optionToBuy\&id=1974-01085-001 


\section{RESULT AND DISCUSSION}

Below be stated the descriptive statistics for "score keeping" based on uses questionnaire. Based on Table 2, 4, 6, and 8, which be varied of score for each variables from a score of 1 until score 5 , showed relatively large scores at 4 and 5 which show the relative effectiveness for role of theory of agency and the role of institutional theory in planning and establishment of direct expenditure. AECnwhile, based on table 3, 5, 7, and 9, shows that the direct expenditure for social welfare efforts to achieve relatively more dominant than focus on meeting the competitiveness of regional competitiveness towards the AEC.

Table 2. Number Frequency of responses (Fo): Aspects of the agency theory

\begin{tabular}{ccccccc}
\hline Frequency of Scores & 1 & 2 & 3 & 4 & 5 & Total \\
Responses of GWUs & 1 & 1 & 4 & 22 & 53 & 81 \\
\hline
\end{tabular}

Scores 4 and 5 has achieved with a relatively large up to 92.59 percent. It showing a High effectiveness and a positive response in the ranks GWUs to accept aspects of agency theory.

Table 3. Responses for Role of Theory of Agency

\begin{tabular}{lcc}
\hline Indicators to be considered & $\begin{array}{c}\text { Ful- } \\
\text { filled }\end{array}$ & $\begin{array}{c}\text { Not Ful- } \\
\text { filled }\end{array}$ \\
\hline $\begin{array}{l}\text { Determination of capital expenditure carried out on the basis of the effec- } \\
\text { tiveness of the performance of public services }\end{array}$ & 77 & 5 \\
$\begin{array}{l}\text { Determination of capital expenditure can be realized related to the budget } \\
\text { yearly; }\end{array}$ & 58 & 24 \\
$\begin{array}{l}\text { Capital expenditures carried out according to the needs of society-private } \\
\text { (as principals/stakeholders); }\end{array}$ & 74 & 8 \\
$\begin{array}{l}\text { Capital expenditure of GWUs has full information for held accountable } \\
\text { meet fairness in the assessment of the auditor; }\end{array}$ & 80 & 2 \\
\begin{tabular}{l} 
Capital expenditure of GWUs with need rationality for development \\
\hline
\end{tabular} & 79 & 3 \\
\hline
\end{tabular}

Determination of capital expenditure which can be realized related to the budget yearly is lower than the indicators others of theory of agency. This AECn that in stages after determination of budget work plan be stated many aspects to be considered. Regional government face the contingency aspects with the environment in line with their duty to take policy action. In this policy, management of GWUs in Regional government should take and anticipate regulation "ex ante" or "ex post" for decision in planning and to realize capital expenditure in Budget execution document for regional budget yearly.

Table 4. Number Frequency of responses (Fo): Aspects of the Institutional theory

\begin{tabular}{lllllll}
\hline Frequency of Scores & 1 & 2 & 3 & 4 & 5 & Total \\
\hline Responses of GWUs & & 1 & 6 & 22 & 52 & 81 \\
\hline
\end{tabular}

Scores 4 and 5 has achieved with a relatively large up to 91.36 percent. It showing a High effectiveness and a positive response in the ranks GWUs to accept aspects of institutional theory. 
Table 5. Responses for Role of Institutional Theory

\begin{tabular}{lcc}
\hline Indicators to be considered & $\begin{array}{c}\text { Ful- } \\
\text { filled }\end{array}$ & $\begin{array}{c}\text { Not Ful- } \\
\text { filled }\end{array}$ \\
\hline $\begin{array}{l}\text { Capital expenditures are set in consideration of the limited funds } \\
\text { available }\end{array}$ & 79 & 3 \\
$\begin{array}{l}\text { In } 3 \text { years final, capital expenditure has increased } \\
\begin{array}{l}\text { Direct Expenditure on Government Work Unit (GWU) considering } \\
\text { the aspects of efficiency and economical }\end{array}\end{array}$ & 80 & 26 \\
$\begin{array}{l}\text { Capital expenditure as a budget framework in accordance with the } \\
\text { reference regulations }\end{array}$ & 80 & 2 \\
$\begin{array}{l}\text { Capital expenditures on Government Work Unit (GWU) to support } \\
\text { the economic activities of society - private; }\end{array}$ & 73 & 79 \\
\hline
\end{tabular}

Based on AECsurement indicator the increasing of capital expenditure in 3 years showed low achievement of positive responses from GWUs in line with institutional theory. Nominal growth of plan for direct expenditure and regional expenditure of Sampling unit of Regional Government:

Table 6. Nominal growth of plan for direct expenditure and regional

\begin{tabular}{ccc}
\hline Year & Direct Expenditure & Regional Expenditure \\
\hline 2011 & $397.954 .817 .291,00$ & $924.607 .371 .591,00$ \\
2012 & $552.430 .995 .879,00$ & $1.130 .039 .190 .774,00$ \\
2013 & $769.127 .801 .254,00$ & $1.444 .700 .363 .596,00$ \\
2014 & $798.087 .181 .790,00$ & $1.468 .054 .133 .839,00$ \\
2015 & $767.583 .763 .845,00$ & $1.764 .174 .168 .887,00$ \\
2016 & $774.036 .073 .572,00$ & $1.800 .319 .581 .272,00$ \\
\hline \multicolumn{3}{l}{ Source: Financial Affair of Regional Government, 2016 }
\end{tabular}

The ratio of the growth in planning of "direct spending" (2011-2016): 39.04\% (2012); $39.31 \%$ (2013); $3.77 \%$ (2014); -3.88\% (2015); $0.91 \%$ (2016). The ratio of "capital expenditure" to the amount of direct expenditure (Personnel expenditure, spending on goods and services, and capital expenditure) in the years 2011 to 2015: $48.11 \%$ (2011); 55, 98\% (2012); $57.09 \%$ (2013); $47.99 \%$ (2014); $41.59 \%$ (2015). The ratio of capital expenditures to the regional expenditure (consisting of indirect expenditures and direct spending) (2011-2016): 20.67\% (2011); 27.34\% (2012); 30.40\% (2013); $26.09 \%$ (2014); $18.08 \%$ (2015); 17.38\% (2016). The ratio of capital expenditures to capital expenditure plan (2011-2014): $79.58 \%$ (2011); $75.08 \%$ (2012); 68.56\% (2013); 86.42\% (2014). The realization ratio of direct expenditures of the plan (2010-2015): $31.54 \%$ (2011); 61.78\% (2012); $42.07 \%$ (2013); - $12.76 \%$ (2014); - $16.71 \%$ (2015).

Growth in direct spending of local government is not always grow up or progressive and even in fact has negative growth due to various conditions. One important thing is the tight expenditure requirements directly related to capital expenditure to meet the suitability for good project and accountable. Because a project is bounded by its results, time, and resources, it is often necessary to make tradeoffs among results, time, and resources, the three elements (or "parameters") by which a project is bound. Thus, project management is the process of developing substantive, systematic data about each parameter in order to maximize the effectiveness of the tradeoff decision. The project management process is itself a series of steps typically represented by a "project management process model." (HBS, 2002). 
As author and Harvard Business School professor Robert Austin has stated:"Conventional project management methodologies work best when the chances are really good that the project will unfold as anticipated during its planning stages, when there is little that can happen during the project that planners can't see coming, when you can formulate responses to contingencies in advance. In other words: when there is not much genuine discovery going on." He points to building construction as an example, where the range of potential problems often can be anticipated and solutions planned in advance. The traditional tools of project management, however, are less useful when uncertainty is high. Something more is required: adaptability. (HBS, 2012). Referring to theory of agency, we can refer for the "Note, however, that some companies separate the role of the project "owner" from that of project manager. The owner takes care of meeting the business needs, and the manager is responsible for timely delivery. Yet even in this case, you cannot remove the team and its leader from their responsibility to make sure that their day-to-day work leads to the longterm success of the end result. (Shenhar \& Dvir, 2007).

We can to explain the function and role of an integrative approach in budgeting planning and realization of direct spending referring Project Cycle Managemment (PCM) with The basic format or structure of project and programme documents. "A basic 'format' is applied for all documents to be produced during the project cycle. It follows the core logic of the Logical Framework Approach. This model can be stated consits of: 1. Summary; 2. Background: Overall EC and Government policy objectives, and links with the Commission's country programme or strategy, commitment of Government to over-arching policy objectives of the EC such as respect of human rights; 3 . Sectoral and problem analysis, including stakeholder analysis and their potentials; 4 . Project / programme description, objectives, and the strategy to attain them Including lessons from past experience, and linkage with other donors' activities Description of the intervention (objectives, and strategy to reach them, including Project Purpose, Results and Activities and main Indicators); 5. Assumptions, Risks; 6. Implementation arrangements: Physical and non-physical AECns, Organisation and implementation procedures, Timetable (work plan), Estimated cost and financing plan, Special conditions and accompanying AECsures by Government / partners, Monitoring and Evaluation; 7. Quality factors: Participation and ownership by beneficiaries, Policy support, Appropriate technology, Socio-cultural aspects, Gender equality, Environmental protection, Institutional and management capacities, Financial and economic viability Annex: Logframe (completed or outline, depending on the phase) "(EC, 2002).

Based on concept, determining a planning and budgeting is as the clarity of the process and the purpose of establishing the programs and activities which described by the stage set financial value on the aspect of "shopping" at every program and activity. A direct expenditure such as capital expenditure considered appropriate to be stated in Budget Work Plan (BWP) and in Budget Execution Document (BED) when can meet the characteristics referring to Accounting for Research and Development Costs, which fulfill cost recognition, namely: "Three pervasive principles for recognizing costs as expenses are set forth in paragraphs 156-160 of APB Statement No. 4 as follows: Associating Cause and Effect, Systematic and Rational Allocation, Immediate Recognition... (FASB, SFAC No. 2, 1974).

Table 7. Number Frequency of responses (Fo): Aspects of Social Welfare

\begin{tabular}{ccccccl}
\hline Frequency of scorers & 1 & 2 & 3 & 4 & 5 & Total \\
Responses of GWUs & 2 & 10 & 13 & 16 & 39 & 80 \\
\hline
\end{tabular}

Scores 4 and 5 has achieved with a relatively large up to 68,75 percent. It showing a effectiveness enough and "cukup memenuhi" a positive response in the ranks GWUs to accept aspects of social welfare. 
Table 8. Responses for Role of Aspects of Social Welfare

\begin{tabular}{lcc}
\hline Indicators to be considered & $\begin{array}{c}\text { Ful- } \\
\text { filled }\end{array}$ & $\begin{array}{c}\text { Not Ful- } \\
\text { filled }\end{array}$ \\
\hline $\begin{array}{l}\text { Capital expenditure on GWUs can fulfill the facilitation of sectoral develop- } \\
\text { ment for basic services }\end{array}$ & 74 & 8 \\
$\begin{array}{l}\text { Facilitating the GWU can meet growing business / leading sector in the re- } \\
\text { gions }\end{array}$ & 63 & 19 \\
$\begin{array}{l}\text { Facilitate GWU in the development of cross-sector basic services District / } \\
\text { City }\end{array}$ & 53 \\
$\begin{array}{l}\text { Capital expenditure on GWU meets the constraints of handling basic services } \\
\begin{array}{l}\text { Capital expenditure on GWU related to the provision of facilities and infra- } \\
\text { structure sectors; }\end{array}\end{array}$ & 63 & 19 \\
\hline
\end{tabular}

Medium Term Development Plan (MTDP) is a description of the Vision, Mission, Regional Header programme by referring to the region and noticed Long Term Development Plan (LTDP) National. Contents of MTDP consists of :

1. The Regional Development Strategy

2. Public Policy

3. Direction of Regional Financial Policy

4. Programme of GWUs, Cross- GWUs, territorial, and cross-regional which includes activities in: Regulatory framework and Budget framework.

The low achievement of development with the facilitation of cross-regional direct spending, requires the support and strengthening of capital expenditures of GWUs in the Regional Government. This is necessary for the implementation of the budget can be effectively towards social welfare achievement. The relevance of planning decisions and realization of capital expenditure has implications for good governance to achieve the purpose of social welfare by empowering role of the budget towards social welfare. This is spelled out through programs and activities to enhance (i) economic growth, (ii) employment, (iii) reduce poverty, and (iv) environmental protection. Direct spending, both capital expenditures for personnel, goods and services, and for capital goods should be fulfilled government in fulfillment for social welfare. Regional government need to enhance social welfare achievement with planning and realization for capital expenditure. This context in line with (Thomas et al., 2016: 218) in new approach to management theory and social welfare : themes and contributions (Thomas et al., 2016) they stated : "two themes emerge, First, fairness and justice are argued.

Table 9. Number Frequency of responses (Fo): Aspects of AEC

\begin{tabular}{ccccccc}
\hline Frequency of Scorers & 1 & 2 & 3 & 4 & 5 & Total \\
Responses of GWUs & 3 & 8 & 16 & 12 & 38 & 77 \\
\hline
\end{tabular}

Scores 4 and 5 has achieved with a relatively large up to 64.94 percent. It showing a effectiveness enough and "cukup memenuhi" a positive response in the ranks GWUs to accept aspects of ASEAN Economic Community (AEC). 
Table 10. Responses for Role of Aspects of AEC

\begin{tabular}{lcc}
\hline $\begin{array}{l}\text { Indicators to be considered } \\
\begin{array}{l}\text { Policy-related capital expenditure budget for the empowerment of } \\
\text { human resources quality basic service sector competition. }\end{array}\end{array}$ & $\begin{array}{c}\text { Ful- } \\
\text { filled }\end{array}$ & $\begin{array}{c}\text { Not Ful- } \\
\text { filled }\end{array}$ \\
$\begin{array}{l}\text { Framework for capital expenditure budget to support the empowerment } \\
\text { of single market competition }\end{array}$ & 41 & 41 \\
$\begin{array}{l}\text { Frameworkfor capital expenditure budget to support the empowerment } \\
\text { of competition production base }\end{array}$ & 57 & 25 \\
$\begin{array}{l}\text { Policies capital expenditure to support the strengthening of physical } \\
\text { infrastructure }\end{array}$ & 67 & 15 \\
$\begin{array}{l}\text { Policies capital spending supported the strengthening of the system } \\
\text { infrastructure. }\end{array}$ & 65 & 17 \\
\hline
\end{tabular}

Strategies for capital expenditure as part of direct expenditure is related to the strengthening of regional competitiveness in AEC. Determination of Budget Work Plan and for Budget Execution Document as budget strategy for : (i) Strategic Program / Administrative / Socio / Technical to support private sector in region referring to compete in single market and production base that includes five (5) core elements, namely: (i) free flow of goods; (Ii) free flow of services; (Iii) the free flow of investment; (Iv) the free flow of capital; and (v) free flow of skilled labor. The agreement also includes two important components, namely: the priority integration sectors, food, agriculture and forestry, (ii) for Strategic program / Administration / Socio / Technical for strengthening of regions as Competitive Economic Region of AEC. (iii) Implementation of Pillar 3 through relevance BWP and BED as Strategic program / Administration / Socio / Technical for strengthening Regions towards Equitable Economic Development, such as to: SME development; Initiative for ASEAN Integration, and (iv) Implementation of Pillar 4 with BWP and BED asStrategic program / Administration / Socio / Technical for strengthening regions towards Integration into the Global Economy

Related research describes that: "Each countries has different result. Moreover, the situation of foreign direct investment in every contries at the time before AEC starts also shown the difference. The research emphasizes on one of the main objectives of the AEC itself the single market and production base..., it can be seen we predicted FDI towards the implementation of the AEC has increased, despite the fact that before we know the AEC, ASEAN contries themselves have imposed the name Regional Economic Integration (REI). Where AEC is the sustainability of the REI so can we assume the effects before and after the AEC is FDI will continue to increase in the countries that joined in ASEAN" (Darma \& Achmad, 2013).

\section{Hypothesis Test}

Frequency AECsurement data with each five (5) indicators on the 4 (four) study variables presented through the following table:

Table 11. Contingency \& Chi Squared Table- Observation

\begin{tabular}{llcccc}
\hline Variables & Agency & Institutional & $\begin{array}{c}\text { Social } \\
\text { Welfare }\end{array}$ & AEC & Total \\
\hline Implementation Pillars of & & & & \\
AEC & & & & \\
Very Implementable & & &
\end{tabular}


Score 5 (Fo)

$\mathrm{Fe}$

Implementable

Score 4 (Fo)

Fe

Sufficient Implementable

Score 3 (Fo)

$\mathrm{Fe}$

Less Implementable

Score 2 (Fo)

$\mathrm{Fe}$

Not Implementable

Score 1 (Fo)

$\mathrm{Fe}$

$\mathrm{N}$ (total of Responses)
53

52

39

38

182

$\begin{array}{llll}46.21316614 & 46.21316614 & 45.64263323 & 43.93103448\end{array}$

22

22

16

12

72

$\begin{array}{llll}18.28213166 & 18.28213166 & 18.05642633 & 17.37931034\end{array}$

13

16

39

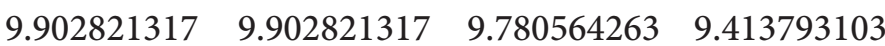

$\begin{array}{lllll}1 & 1 & 10 & 8 & 20\end{array}$

$\begin{array}{llll}5.078369906 & 5.078369906 & 5.015673981 & 4.827586207\end{array}$

1

0

2

6

$\begin{array}{llll}1.523510972 & 1.523510972 & 1.504702194 & 1.448275862\end{array}$

81

80 319

Based on data in Chi Squared Table (observation) above will use to determine $\mathrm{Xo}^{2}=\mathrm{Chi}$ squared observations with $\mathrm{N}$ as number of responses in observation.

Table 12. Chi Squared Observation

\begin{tabular}{|c|c|c|c|c|c|}
\hline \multirow[t]{3}{*}{ Variables } & Agency & Institutional & Social Welfare & $\mathrm{AEC}$ & \multirow[t]{3}{*}{ Total } \\
\hline & 6.786833856 & 5.786833856 & -6.642633229 & -5.931034483 & \\
\hline & 46.06111379 & 33.48744607 & 44.12457621 & 35.17717004 & \\
\hline \multirow[t]{3}{*}{$\begin{array}{l}\text { Xo Observa- } \\
\text { tion }\end{array}$} & 0.996709761 & 0.724629989 & 0.966740372 & 0.80073621 & \multirow[t]{3}{*}{3.488816331} \\
\hline & 3.717868339 & 3.717868339 & -2.056426332 & -5.379310345 & \\
\hline & 13.82254498 & 13.82254498 & 4.22888926 & 28.93697979 & \\
\hline \multirow[t]{3}{*}{$\begin{array}{l}\text { Xo Observa- } \\
\text { tion }\end{array}$} & 0.756068561 & 0.756068561 & 0.23420411 & 1.665024631 & \multirow[t]{3}{*}{3.411365863} \\
\hline & -5.902821317 & -3.902821317 & 3.219435737 & 6.586206897 & \\
\hline & 34.8432995 & 15.23201423 & 10.36476646 & 43.37812128 & \\
\hline \multirow[t]{3}{*}{$\begin{array}{l}\text { Xo Observa- } \\
\text { tion }\end{array}$} & 3.518522488 & 1.538148952 & 1.05973093 & 4.607932298 & \multirow[t]{3}{*}{10.72433467} \\
\hline & -4.078369906 & -4.078369906 & 4.984326019 & 3.172413793 & \\
\hline & 16.63310109 & 16.63310109 & 24.84350586 & 10.06420927 & \\
\hline \multirow[t]{3}{*}{$\begin{array}{l}\text { Xo Observa- } \\
\text { tion }\end{array}$} & 3.275283486 & 3.275283486 & 4.953173981 & 2.084729064 & \multirow[t]{3}{*}{13.58847002} \\
\hline & 0.523510972 & -1.523510972 & 0.495297806 & 1.551724138 & \\
\hline & 0.274063738 & 2.321085681 & 0.245319916 & 2.4078478 & \\
\hline
\end{tabular}


Xo Ob-

servasi

The coefficient of Contingency (Contingency $\mathrm{C}$ ) obtained by the formula:

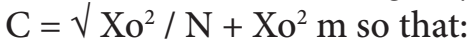

$\mathrm{C}=\sqrt{ } 34.74 / 319+34.74=0,313$, where: $\mathrm{Xo}^{2}=$ Chi squared observations is 34.74 and

$\mathrm{N}=$ number of responses in observation is 319

Contingency coefficient value is also calculated based on the formula Cramer Coeefficient of Association, namely: $\mathrm{C}=\sqrt{ } \mathrm{Xo} 2 / \mathrm{N}(\mathrm{L}-1)$ for $\mathrm{L}=\min (\mathrm{b} x \mathrm{k})$, where:

$C=\sqrt{ } 34.74 / 319(4-1)=0,191$

$\mathrm{X} 2$ table is determined according to the Chi-Square table, namely the (row - 1) $\mathrm{x}$ (column 1) with value 21,026 . Referring to the results of study, where $X 2$ Observation 34,742 is greater than X2 table, namely 21.026. This is indication and justify the differences in the implementation of capital expenditure to meet AEC pillars and social welfare purposes through the role of the agency theory, and institutional theory. Interpretation of the value of Contingency coefficient referring to Guilford's Empirical Rule, shows that $\mathrm{C}=$ coefficient value is limited ie associations between $0<1$, where: $0=$ no associations/relationship and $1=$ a perfect associations/relationship. Relationship of agency theory and institutional theory with social welfare and AEC Based on the amount of C Contingency coefficient is 0,313 , and with Cramer Coefficient of Association is 0.191 . This is indication that there is a relationship between the implementation for capital expenditures to meet AEC pillars and social welfare purposes through the role of the agency theory, and institutional theory. Based on the Guilford Empirical Rule indicates the degree of association between variables, which for coefficient C Contingensi is amounted to 0.313 can be stated as "Small correlation ; low relationship ". While based on the Cramer, showed coefficient 0.191 as "Slight correlation : almost negligible relationship".

\section{CONCLUSIONS}

Implementation for planning and realization for capital expenditures as regional investment which has done by regional government for social welfare and support facilitation of regional competitiveness in an era of AEA, reached via the main tasks and functions of each GWU. The function and role in the implementation unit to manage aspects of the development towards social welfare to citizens is appropriate with Development Plan for Long Term / Development Plan for Mid Term, Pillars of AEC, and even with the implications for the MDGs, SDGs as a global issue of development. This includes the implementation of capital expenditure through Principal task and function of GWUs, namely for services or functions: (i) Planning and control of development; (ii) Planning, utilization and control layout; (iii) The conduct of public order and public tranquility; (iv). Provision of facilities and general infrastructure; (v) Handling the field of health; (vi) Implementation of education and allocation of human resources potential; (vii) handling social problems; (viii) Services field of employment ; (ix) Facilitate the development of cooperatives and small and medium enterprises; (x) Control of the environment; (xi) Service for land; (xii) Population Services, and civil; (xiii) Administrative services general government; (xiv) investment administration services; (xv) Other basic services.

Capital expenditures as investment needs can be managed in the pattern: (i) the fulfillment of capital expenditure which fulfill return of economic benefits and social benefits of capital goods in the construction (ii) For increasing of development services for the changes and demands of 
development, such as AEC as part of globalization, the competitiveness of regions other than the basics in social development and economic development (iii) the need of improvement, innovation, invention and breakthrough in enhancing the value of life in development that requires the fulfillment of direct expenditure with capital expenditure. (iv) In control of planning and controlling administrative expenditure management expenditure referring to capital expenditure in compliance with the inventory value of capital expenditure and capacity services for development.

In an global era, the capital expenditure planning and realization is a unity, so that, the relevance of the plan are achieved can asserts that the plan and realization of capital expenditure is not always because of the large numbers in the budget, but because of according to the conditions and the strength of the regional budget. We can refers for relevant situation with policy in planning and realization for Budget Work Plan (BWP) and Budget Execution Document (BED) with the qualitative policy of "Charles Darwin" referring to the Survival of the fittest, the which stated: "' It is not the strongest of the species that survives, nor the most intelligent, but the one most responsive to change ". This idiomatic phrases stressed that theories will give role for regulation functions as "ex ante" to predict for decision which will taken, and as ex post to control for impact of decision.

According to the results of the study, referring to contingency aspect, showed there was the role of agency theory and institutional theory in the implementation of the planning and realization of capital expenditure, but the role that has shown in this relationship was too low related with social welfare goal and for strengthening regional competitiveness in an era of AEC. Low role is indicated by: (i) Determination of capital expenditure can be realized related to the budget yearly (Theory of Agency); (ii) In 3 years final, capital expenditure has increased (Institutional Theory); (iii) Facilitate GWU in the development of cross-sector basic services District / City (Social welfarre aspect), and (iv) Framework for capital expenditure budget to support the empowerment of single market competition (AEC aspect).

Need to strengthen the role of the agency theory and the institutional theory to achieve empowerment for the role of regulation with dimension, namely: (i) goal clarity, (ii) completeness of regulation forms, (iii) acceptance of regulation, and (iv) easiness to apply, which became foundation in the control phase of the establishment of the planning and realization of capital expenditure in regional government in global era.

\section{REFERENCES}

Aaron J. Shenhar, Dov Dvir, HBS, 2007, What Makes a Project Successful, Excerpted from Reinventing Project Management: The Diamond Approach to Successful Growth and Innovationwww.HBSPress. org,

Adi, Priyo Hari, 2006, The Relationship Between Regional Economic Growth, Developmnet Expenditure and Regional Origin Revenue, National Symposium Accounting 9 Padang, 23 to 26 August 2006

Agung Riyard, Widojono, Muzakir Isa, Agung Riyard, Widojono, Muzakir Isa, 2013, Analysis of the Sragen Local Governmennt Organizational Capacity, Proceeding, The 14th MIICEMA Conference, AEC 2015, Issues and Challenges, October 9-10th , 2013, Bogor, Indonesia, p. 74-82

Ali Sulieman Al-Shatti, 2014, The Impact of Public Expenditures on Economic Growth in Jordan, International Journal of Economic and Finance, Vol. 6, No 10, 2014, Published by Canadian Center of Science and Education.

Andreas Irmen and Johanna Kuehnel, 2008, Productive Government Expenditure and Economic Growth, Discussion Paper Series No. 464, Andreas Irmen ; University of Heidelberg, CEPR, London, and CESifo, Munich; Johanna Kuehnel, University of Heidelberg

BO Rothstein and Ditlind Stolle, 2001, Social Capital and Street -Level Bureaucracy: An Institutional Theory of Generalized Trust, Center for The Study Democratic Politics, Princeton University, UK,

Brownell P, 1982, The Role of Accounting Data in Performance Evaluation, Budgetary Participation and Organizational Effectiveness, Journal of Accounting Research, Vol 23, No. 3, pp: 124-153

Carpenter L Vivian \& Feroz, H, Ehsan, 2001. Institutional Theory and Accounting Rule Choice: An Analysis 
of Four US State Governments' Decisions To Adopt Generally Accepted Accounting Principle, Accounting, Organizations, and Society, Florida, USA,

Development Center Accounting (PPA) Faculty of Economic and Bussiness ULM, 2016, Road Map To Competitiveness AEC of Banjar District (2016-2020-2025), Board of Planning and Regional Development Banjar district

Dharma Rika Swaramarinda \& Achmad fauzi, 2013, The Impact of ASEAN Economic Community (AEC) on Foreign Direct Investment, Proceeding, The 14th MIICEMA Conference, AEC 2015, Issues and Challenges, October 9-10th, 2013, Bogor, Indonesia, p. 101-109.

DiMaggio PJ and Powel W W, 1983, The Iron Cage Revisited: Institutional Isomorphism and Collective Rationallity in Organizational Fields, American Sociological, No 48. Pp 147-160

Eisenhartd, Kathleen M, 1989, Agency Theory: An Assessmet And Review, Academy of management Review No 14 (1), pp 57-74

EUROPEAN COMMISSION EuropeAid Co-operation Office General Affairs Evaluation, 2002, Project Cycle Management Handbook, FTP International Ltd., FIN-00101 Helsinki, Finland Prospect C\&S, B-1000 Brussels, Belgium South Research, B-3010 Kessel-Lo, Belgium

FASB, 1974, SFAS No 2, About Accounting for Research and Development Costs, in paragraphs 156-160 of APB Statement No. 4 as follows: Associating Cause and Effect. Systematic and Rational Allocation. Immediate Recognition.

FASB, 1980, Qualitative Characteristic of Accounting Information, Statement of Financial Accounting Concept No. 2

Garamfalvi, L. 1997. Corruption in the public expenditures management process. Paper presented at 8th International Anti-Corruption Conference, Lima, Peru, 7-11 September. http://www.transparency. org/iacc/8th_iacc/papers/garamfalvi/garamfalvi.html.

Government regulation Number 24 Year of 2005 About Governmental Accounting Standard

Governmental Regulation Number 8 Year of 2006 About Financial Reporting and Performance of Governmental Institution

Governmental regulation Number 56 Year of 2005 About Regional Financial Information System

Governmental Regulation Number 58 Year of 2005 About Regional Financial Management

Governmental Regulation Number 71 Year of 2010, About Govermental Accounting Standard

Govindarajan, V, 1986, Impact of Participation in The Budgetary Process on Managerial Attitudes and Performance; Universalistic and Contingency Perspective, Decision Sciences; 496-516

Handoko, Hadiyanto, 2013, The Influences of Expenditure Development and Labor Force to The Economic Growth in Bengkulu Province, Proceeding, The 14th MIICEMA Conference, AEC 2015, Issues and Challenges, October 9-10th , 2013, Bogor, Indonesia, p. 176-180

Harvard Business Review, Nadim F Matta and Ronald N Ashkenas, 2003, Why Good Project Fail Anyway, Best Practice, www.hbr.org.

Harvard Business Scholl (HBS), 2002, Project Management Manual, Rev. March, 26, 2002, http://www. hbsp.harvard.edu.

Harvard Business School, 2006, Project Adaptation: Dealing With What You Cannot Anticipate, Excerpted from Managing Projects Large and Small: The Fundamental Skills for Delivering on Budget and on Time, Harvard Business School Press, Boston, Massachusetts

Horn, John L.; Knapp, John R., On the subjective character of the empirical base of Guilford's structureof-intellect model, Psychological Bulletin, Vol 80(1), Jul 1973, 33-43. http://psycnet.apa.org/index. $\mathrm{cfm}$ ?fa=buy.optionToBuy\&id=1974-01085-001

Institute for Research \& PKM UNLAM, 2015, Report: Road Map To the AEC 2015 For City Government (2016-2020), Section Economic Secretariat of the Government of Banjarmasin

Jensen, C, Michael and Meckling, H William, 1976, Theory of The Firm: Managerial Behaviour, Agency Costs and Ownership Structure, Journal of Financial Economics, Harvard,

Johan Lundberg Fil lic., 2001, Local Government Expenditures and Regional Growth in Sweden, Umeå Economic Studies No. 554,148 pages. (https://www.google.co.id/?gws_rd=cr\&ei=BLWWV8TDOo T7vgSOrILgDA\#q=direct+expenditure+in+regional+government)

Jones, Charles O, 1984, An Introduction to The Study of Publik Policy, California Wadsworth Inc.

Kren, Leslie, 1997. The Role of Accounting Information in Organizational Control: The State of The Art, Behavioral Accounting Research, Foundation and Frontiers, AAA, Connecticut, USA,

Luc E Leruth and Elisabeth Paul, 2006, A Principal-Agent Theory Approach to Public Expenditure Management Systems in Developing Countries (EPub), IMF, https://books.google.co.id/books?hl=i 
$\mathrm{d} \& \mathrm{id}=Y Z \mathrm{Zb} 85$ tnLlEC\&dq=agency+theory+and + expenditure+growth\&q=

Moh Mahfud. MD, The Role of Law in escorting Sovereignty and Development In Indonesia Toward AEC 2015, Prime Lecture Graduate Program UNLAM, Saturday, September 5, 2015

Nworji, Ifeanyi Desmond; Okwu, Andy Titus; Obiwuru Timothy C.; and Nworji, Lucy Odiche, 2012, Effects of Public Expenditure on Economic Growth in Nigeria: A Disaggregated Time Series Analysis, International Journal of Management Sciences and Business Research, 2012, Vol. 1, Issue 7. (ISSN: 2226-8235)

NZIER, New Zealand Institute of Economic Research, Report to MBIE and Treasury, 2013, Regional Governmment Expenditure, Estimate of Core Crown Spending by Region, Grand Thornton House, 251 Lambton Quay, Wellington 6140, econ@nzier.org.nz

Otley, D \& Berry A.J, 1980, Control, Organizations and Accounting, Accounting Organization and Society, 231-244

Regulation of Ministry of Internal Affair Number 4 Year of 2008 About Guidance for Review of Financial Statement of Regional Government

Regulation of Ministry of Finance Number 46 Year of 2006 About Communicating of Regional Financial Information

Regultion of Ministry of Internal Affair Number 13 Year of 2006 About Regional Financial Management Guidance

Regultion of Ministry of Internal Affair Number 59 Year of 2007 About Regional Financial Management Guidance

Shah, Anwar, 2007, Public Sector Governance and Accountability Series; Participatory Budgeting, The World Bank, Washington. DC

ShantaYana Devarajan; Vinaya Swaroop; Heng- Fu Zou, 1996, The Composition of Public Expenditure and Economic Growth, Elsevier, Journal of Monetary Economics 37, p 313-344

Sidik Machfud,, 2007, A New Perspective Of Intergovernmental Fiscal Relations, Lessons From Indonesia’s Experience, Edition 1st, PT Insan Muda Gemilang, Jakarta,

Smith, Robert W. \& Mark Bertozzi. 1998. Principals and agents: An explanatory model of public budgeting. Journal of Public Budgeting, Accounting and Financial Management (Fall): 325-353.

Syaiful Hifni, 2012, Policy Implementation For Regional Revenues Management Toward Regional Budget's Empowerement in South Kalimantan, The 11 th IRSA International Conference, Banjarmasin, 9-11 JULY,

Thinking Globally, Prospering Regionally ASEAN Economic Community 2015, General information on ASEAN appears online at the ASEAN Website: www.asean.org

Thomas M Jones, Thomas Donaldson, R. Edward Freeman, Jeffrey S. Harisson, Carrie R. Leana, Joseph T. Mahoney, and Jone L Pearce, 2016, Academy on Management Review, Volume 41, No 2, pp 216-228

Todaro, P. Michael , 2006, Ilmu Ekonomi Bagi Negara Dunia Ketiga ( Economic Science for The Third World Country ), VII Edition, Jakarta

2013, Dissertation, Antecedent Implementation Accounting System and The Qonsequences Toward Performance of Information System (Study of Regional Government in South Kalimantan), Dissertation, Airlangga University, Surabaya

UU RI Number 1 Year of 2004 About State Treasury

UU RI Number 15 Year of 2004 About Auditing Management and State Finance Accountability

UU RI Number 17 Year of 2003 About State Finance 